Mariusz Dzieweczyński

Uniwersytet Wrocławski

\title{
Recepcja symboli narodowych zjednoczonych Niemiec po 1990 roku na przykładzie niemieckiego hymnu narodowego
}

Niewiele tekstów literackich może pochwalić się tak długą, a zarazem różnorodną historią recepcji, jak napisany w 1841 roku przez Augusta Heinricha Hoffmanna von Fallerslebena utwór Pieśń Niemców. Niewiele jest również zdań w języku niemieckim charakteryzujących się podobną rozpoznawalnością (nawet wśród osób nie posługujących się tym językiem) jak „Deutschland, Deutschland über alles” („Niemcy, Niemcy ponad wszystko”), czyli pierwsze słowa wspomnianej pieśni, której trzecia zwrotka służy dzisiaj za hymn naszych zachodnich sąsiadów. Także w Polsce hasło nadal wywołuje silne emocje i skojarzenia.

Deutschland, Deutschland über alles,

Über alles in der Welt,

Wenn es stets zu Schutz und Trutze

Brüderlich zusammenhält.

Von der Maas bis an die Memel,

Von der Etsch bis an den Belt,

Deutschland, Deutschland über alles,

Über alles in der Welt!

Deutsche Frauen, deutsche Treue,

Deutscher Wein und deutscher Sang

Sollen in der Welt behalten

Ihren alten schönen Klang,

Uns zu edler Tat begeistern 
Unser ganzes Leben lang.

Deutsche Frauen, deutsche Treue,

Deutscher Wein und deutscher Sang!

Einigkeit und Recht und Freiheit

Für das deutsche Vaterland!

Danach lasst uns alle streben

Brüderlich mit Herz und Hand!

Einigkeit und Recht und Freiheit

Sind des Glückes Unterpfand;

Blüh im Glanze dieses Glückes,

Blühe, deutsches Vaterland! ${ }^{1}$

W bogatej tradycji recepcji niemieckich symboli narodowych hymn stanowi wyjątkowy przypadek. Problematykę trafnie podsumował Hermann Kurzke: „Pieśń Niemców zawsze miała ten sam tekst, w rzeczywistości jednak każda generacja śpiewała inną pieśń"2. Analiza zmian paradygmatu w obejściu z Pieśna Niemców pozwala bliżej przyjrzeć się zmianom w samoświadomości społeczeństwa niemieckiego w ciągu ostatnich 25 lat.

Dlaczego jeszcze jedna publikacja na temat Pieśni Niemców? Podobne pytanie zadają w swoich monografiach 80 lat „Jedności, prawa i wolności”? (Nie) kończąca się historia niemieckiego hymnu narodowego (2004) oraz Jedność, prawo i wolność (2008) Hans-Georg Meyer i Jürgen Zeichner ${ }^{3}$.

Dotychczasowe monografie, artykuły, programy radiowe i telewizyjne podają te same dane i fakty, bez ich interpretacji. Historia pieśni może być naszkicowana jedynie wtedy, kiedy stosunek Niemców zachodnich do własnego symbolu narodowego postrzegany jest jako odzwierciedlenie ich świadomości narodowej. [...] Stosunek (zachodnich) Niemców do swojego hymnu był i jest wyznacznikiem akceptacji państwa RFN w społeczeństwie ${ }^{4}$.

1 Aktualny tekst niemieckiego hymnu narodowego znajduje się na stronie rządu Republiki Federalnej Niemiec, https://www.bundesregierung.de/Content/DE/StatischeSeiten/ Breg/die-nationalhymne-der-bundesrepublik-deutschland.html (dostęp: 30.06.2016).

2 H. Kurzke, Hymnen und Lieder der Deutschen, Mainz 1990, s. 50.

3 H.G. Meyer, 80 Jahre "Einigkeit und Recht und Freiheit”? Die (un)endliche Geschichte der Deutschen Nationalhymne, Mainz 2004; J. Zeichner, Einigkeit und Recht und Freiheit. Zur Rezeptionsgeschichte von Text und Melodie des Deutschlandliedes seit 1933, Köln 2008 [wszystkie tłumaczenia - M.D.]. We wprowadzeniu Zeichner szczegółowo analizuje stan badań na temat recepcji hymnu. Tamże, s. 7-14.

4 Tamże, s. 7-8. 
Próba dodania do ustawy zasadniczej zapisu na temat hymnu, pytania odnoszące się do tekstu i jego autora w teście na obywatelstwo, recepcja w trakcie Mistrzostw Świata oraz Europy w piłce nożnej (2010 i 2016), masowa imigracja i kryzys uchodźczy - historia recepcji hymnu po 2008 roku, kiedy ukazała się obszerna publikacja Zeichnera, przyjmowała coraz to nowe oblicza i wymaga uzupełnienia. Ponadto odczuwalny jest brak publikacji na temat niemieckiego hymnu narodowego w języku polskim.

Analiza recepcji hymnu wymaga badań na pograniczu wielu dyscyplin - literaturoznawstwa, socjologii, politologii, historii, teorii muzyki, a nawet filatelistyki i numizmatyki ${ }^{5}$.

W ich [Niemców] symbolice narodowej odbija się długi, nieskuteczny bój o wolność, narodową jedność i demokrację - wraz z porażkami, nieudanymi rewolucjami, politycznymi przełomami, wojnami oraz popełnianymi zbrodniami. W tym kraju często dochodziło do kłótni na temat hymnu i flagi, w przeciągu 100 lat sama flaga zmieniała się cztery razy! W sporze o Pieśń Niemców i niemiecki trójkolor alternatywy systemowe znalazły swój najsilniejszy symboliczny wyraz. Czarno-czerwono-złote i trzecia zwrotka Pieśni Niemców oznaczają państwo demokratyczne, czerń-biel-czerwień i pierwsza zwrotka naszego hymnu przeciwstawny temu model autorytarny ${ }^{6}$.

Tekst Pieśni Niemców napisany przez Hoffmanna von Fallerslebena na brytyjskiej wówczas wyspie Helgoland początkowo nie zrobił furory, jak obiecywał to sobie wydawca Hoffmanna Julius Campe, a sam autor kilkadziesiąt lat później zrezygnowany stwierdził, że jego pieśń stała się makulaturą. Po pierwszej wojnie światowej wiersz stał się przedmiotem mitu według którego w bitwie pod Langemarck, w której padło 80000 żołnierzy, Niemcy ruszyli do walki z „Niemcy, Niemcy ponad wszystko” na ustach. Mimo związanych m.in. ze wspomnianą legendą protestów Friedrich Ebert w 1922 roku proklamował pieśn hymnem Republiki Weimarskiej.

Po przejęciu władzy przez narodowych socjalistów pieśn została po raz pierwszy rozerwana, a jej pierwotny przekaz wypaczony - „Deutschland, Deutschland über alles" stało się dla Hitlera hasłem idealnie opisującym jego ambicje ${ }^{7}$. W Trzeciej Rzeszy po pierwszej zwrotce następował hymn SA, Pieśń

\footnotetext{
5 Por. tamże, s. 12.

6 P. Reichel, Schwarz-Rot-Gold. Kleine Geschichte deutscher Nationalsymbole nach 1945, München 2005, s. 7-8.

7 Obszernie na ten temat pisze J. Zeichner, Hut ab, Arm hoch und stramm gesungen! Und was war mit der dritten Strophe? Die Rezeption des Deutschlandliedes im Dritten
} 
Horsta Wessela. Z tą kombinacją Niemcy ruszyli na podbój całej Europy. Dzieło Hoffmanna zostało w konsekwencji zakazane przez Aliantów po drugiej wojnie światowej, ale widmo Holocaustu oraz niespotykanych na taką skalę zbrodni na ludzkości unosi się nad jego pierwszą zwrotką do dzisiaj.

Potrzeba ustanowienia narodowych symboli dla RFN i NRD zapoczątkowała w 1949 roku kolejną burzliwą debatę na temat Pieśni Niemców. Zdecydowanym jej przeciwnikiem był prezydent RFN Theodor Heuss, który zlecił napisanie nowego hymnu Rudolfowi Alexandrowi Schröderowi. Hymn do Niemiec nie uzyskał poparcia w społeczeństwie, a na Igrzyskach w Oslo niemieckim sportowcom towarzyszyła Oda do radości. W ostateczności wygrała opcja kanclerza Konrada Adenauera, który w ramach korespondencji z Heussem w 1952 roku ustalił całą Pieśn Niemców hymnem RFN - z zaznaczeniem, że przy oficjalnych okazjach miała być śpiewana trzecia zwrotka ${ }^{8}$.

Decyzja Adenauera była skutkiem braku demokratyzacji kultury politycznej w Niemczech po 1945 roku i odbiciem nastrojów panujących po wojnie. Część społeczeństwa chciała śpiewać wszystkie trzy zwrotki, bo widziała siebie jako pierwsze ofiary polityki hitlerowskiej. Wołanie o rehabilitację hymnu było po części życzeniem o powrót do normalności bez rozliczenia starego systemu9.

„Decyzja na korzyść Pieśni Niemców pozoruje niemieckiemu społeczeństwu iluzję kontynuacji niemieckiej historii, która faktycznie nie istnieje" napisał w 1952 roku Klaus Peter Schulz ${ }^{10}$. Po wygranej na Mistrzostwach Świata w piłce nożnej w Brnie w 1954 roku publiczność niemiecka spontanicznie zaintonowała pierwszą zwrotkę hymnu, a radio natychmiast zakończyło transmisję. Dla przewodniczącego Gesellschaft für Erziehung und Wissenschaft Hessen Klausa Müllera fakt, iż Pieśn Niemców przebiła się mimo oporu ze strony Heussa był typowym przykładem na to, jak w epoce restauracji po 1945 kontynuowano wiele tradycji, które najlepiej byłoby przerwać ${ }^{11}$.

Reich, [w:] J. Zeichner, Einigkeit, s. 21-37 [Czapki z głów, ręka w górę i prosta postawa! A co z trzecią zwrotką? Recepcja Pieśni Niemców w Trzeciej Rzeszy].

8 Bulletin der Bundesregierung, 06.05.1952, s. 537.

9 J. Zeichner, Einigkeit..., s. 21-37.

10 K.P. Schulz, „Deutschland, Deutschland über alles”. Persönliche Bemerkung zur Nationalhymne, [w:] „Gewerkschaftliche Monatshefte” 1952, nr 6, s. 326.

11 K. Müller, [w:] B. Ortmeyer, Argumente gegen das Deutschlandlied. Geschichte und Gegenwart eines furchtbaren Lobliedes auf die deutsche Nation, Frankfurt am Main 2006 (pierwsze wydanie Köln 1991), s. 2. 
Przed upadkiem muru berlińskiego w głowach nadal krążyła pierwsza zwrotka, natomiast trzecia coraz bardziej postrzegana była w kategoriach utopii $^{12}$. W obliczu zjednoczenia Niemiec w 1990 roku na nowo rozgorzała dyskusja na temat symboli narodowych zjednoczonego państwa, m.in. hymnu narodowego. Sprawa hymnu dla nowej Republiki była szeroko komentowana na łamach broszur, publikacji i prasy.

Najbardziej znany przypadek publicznej krytyki dzieła Hoffmanna von Fallerslebena to wznowiona z okazji zbliżających się Mistrzostw Świata w piłce nożnej w 2006 roku, licząca 180 stron publikacja Benjamina Ortmeyera Argumenty przeciwko Pieśni Niemców. Historia okropnej pieśni na cześć niemieckiego narodu z 1991 roku. Publiczny oraz krytyczny spór o Pieśń Niemców stał się przyczynkiem do racjonalnej dyskusji na temat niemieckiej historii ${ }^{13}$.

Już w przedmowie przewodniczący Gesellschaft für Erziehung und Wissenschaft, Dieter Wunder, wyraził nadzieję na fundamentalne rozliczenie przeszłości w ramach procesu zjednoczeniowego i sformułował żądanie: „Pieśń Niemców nadaje sie do muzeum"14. W dziesięciu rozdziałach Benjamin Ortmeyer przygląda się pieśni z każdej strony. Nie jest to jego zdaniem hymn, który może być kiedykolwiek śpiewany przez ofiary narodowosocjalistycznej dyktatury i ich dzieci, sama melodia ludności żydowskiej kojarzy się z prześladowaniem, strachem i śmiercią. Pierwsza zwrotka przekazuje wielkoniemieckie i imperialistyczne dążenia, natomiast druga jest nie tylko kulturowym kiczem, ale transportuje wrogie kobietom stereotypy. Po streszczeniu genezy tekstu Ortmeyer trzeci rozdział tytułuje „bajeczka o nienagannym prof. Hoffmannie von Fallerslebenie" - z całej twórczości poety autor wybrał fragmenty jego zdaniem nacjonalistyczne, antysemickie i reakcyjne. Rzucając okiem na historię oddziaływania tekstu zaprzeczył panującej opinii, że naziści jedynie „wykorzystali” hymn. Krytyce poddał osoby argumentujące, że „przeciez inni również mają hymny, i to jeszcze gorsze" oraz autora hymnu NRD, Johannesa Bechera.

Parę miesięcy wcześniej Klaus Dede w tekście Wykorzystany hymn (Die missbrauchte Hymne. Ein Plaidoyer von Klaus Dede), nieświadomy przełomu 1989 roku, zabrał głos w debacie na temat Pieśni Niemców. Doszedł do wniosku, że natychmiast należy się jej pozbyć. Ciekawy jest już sam tytuł, w końcu Plaidoyer możemy przetłumaczyć zarówno jako mowę oskarżycielską, jak i obrończą. Mógłby on wskazywać na wielokrotnie przywoływane „wykorzystanie i nadużycie” pierwszej zwrotki przez nazistów i domagać się rehabilitacji tekstu. Nic bardziej mylnego.

12 J. Zeichner, Einigkeit..., s. 21-37.

13 B. Ortmeyer, Argumente....

14 Tamże, s. 2. 


\section{Mariusz Dzieweczyński}

Tekst i tradycja, która kojarzona jest z tym wierszem, jest na zawsze połączona ze wszystkim co w niemieckiej historii najgorsze. Jednego niemieckiego narodu nigdy nie było, nie ma i nigdy nie będzie. Można udowodnić istnienie pewnej świadomości narodowej, lecz tylko na jej kanwie nigdy nie ukonstytuowało się żadne państwo. Pieśń Niemców jest wyrazem ideologii, która stoi w opozycji do ustawy zasadniczej, a dopóki ten tekst jest uznany za „hymn narodowy”, to nacjonalizm jest doktryną państwową, przed którą uginają się wszyscy, którzy go śpiewają, nawet jeśli nie aprobują treści owej „religii”. Wykorzystują hymn wszyscy ci, którzy intonują go teraz, zamiast siedzieć i milczeć, dopóki hymn nareszcie zostanie zapomniany. Wtedy, dopiero wtedy, będzie można powiedzieć, że uporaliśmy się z własną historią, co znaczy tyle, że przezwyciężyliśmy niemiecki nacjonalizm ${ }^{15}$.

Stefan Roeloffs, autor tekstu Pień Niemców nie nadaje się na hymn narodowy (Das Lied der Deutschen taugt nicht zur Nationalhymne) już w pierwszym akapicie zaznaczył, że napisany przez Hoffmanna tekst z perspektywy literackiej nie jest ani piękny, ani ambitny, a nawet w skróconej wersji od 1990 roku stanowi (nieprzemyślany?) wyraz bezguścia i wywołuje niesmak. Autor zaznaczał, że dla Hitlera hymn był świętością, dla Heinricha Heine pieśni Hoffmanna zwiastunem końca niemieckiej poezji.

Jaką funkcję miałby spełniać ten tekst po 1990 roku, poza upamiętnieniem zrealizowanych przecież postulatów jedności, prawa $i$ wolności, przechodzących do historii? Czy postrzega się wypowiedziane w trzeciej zwrotce zadania jako nadal niespełnione? Czy pieśń ma być śpiewana na znak radości i zadowolenia ze stanu doczesnego, $\mathrm{z}$ tego co po zjednoczeniu zostało osiągnięte? O jaką ojczyznę chodzi - tę, która (jeszcze) czeka na zjednoczenie, w której rządzą różne prawa, a wolność stanowi jedynie odległy cel? Być może tekst jest wyrazem swego rodzaju utopii lub sugestii poprawy warunków w kraju - tej interpetacji musiałoby jednak towarzyszyć postawa, że jeszcze wiele jest w nim do zrobienia ${ }^{16}$.

Jednym z najbardziej prominentnych przeciwników Pieśni był Wolf Biermann, śpiewak, poeta, pisarz i dysydent, który po koncercie w Kolonii nie został wpuszczony z powrotem do NRD i któremu odebrano obywatelstwo. Mimo to miasto Corvey, gdzie pochowany jest Hoffmann von Fallersleben, przyznało Biermannowi w 2006 roku wyróżnienie, plakietę Corveyer

15 K. Dede, Die missbrauchte Hymne. Ein Plaidoyer von Klaus Dede, Osnabrück 1989, s. 196.

16 S. Roeloffs, Das „Lied der Deutschen” taugt nicht zur Nationalhymne, [w:] Poetisierung - Politisierung. Deutschlandbilder in der Literatur bis 1848, W. Gössmann, K.-H. Roth (red.), Paderborn, München, Wien, Zürich 1994, s. 335. 
Hoffmann-von-Fallersleben-Plakette. W swojej mowie Biermann porównał do Hoffmanna współczesnych mu Goethego i Heinego, którzy już wtedy według pieśniarza byli dwa wielkie kroki dalej. „Już dawno czuli się Citoyens ludzkości à la Jean-Jacques Rousseau, niekoniecznie patriotycznymi wielkoniemieckimi krasnalami jak Hoffmann"17. W trakcie wystąpienia z okazji rocznicy upadku muru w 2014 roku Biermann potwierdził swoją krytykę i opowiedział się za Kinderhymne Bertolta Brechta, nazywajac go pięknym hymnem, który Niemcy mają „w rezerwie”, a do którego być może jeszcze nie dojrzeli. Szczególnie trzecia zwrotka tekstu Brechta z 1949 roku bezpośrednio nawiązuje do idei i zwrotów zawartych w pierwszej zwrotce Pieśni Niemców, definiując granice Niemiec bez pretensji terytorialnych wobec Polski, Danii, Holandii, Austrii i Włoch. Po zjednoczeniu Niemiec kilka komitetów obywatelskich i mediów zaangażowało się bezskutecznie w kampanię na rzecz ogłoszenia tekstu Brechta nowym hymnem Niemiec.

Anmut sparet nicht noch Mühe

Leidenschaft nicht noch Verstand

Daß ein gutes Deutschland blühe

Wie ein andres gutes Land

Daß die Völker nicht erbleichen

Wie vor einer Räuberin

Sondern ihre Hände reichen

Uns wie andern Völkern hin.

Und nicht über und nicht unter

Andern Völkern wolln wir sein

Von der See bis zu den Alpen

Von der Oder bis zum Rhein.

Und weil wir dies Land verbessern

Lieben und beschirmen wir's

Und das liebste mag's uns scheinen

So wie andern Völkern ihrs ${ }^{18}$.

17 W. Biermann, Wolf Biermann erklärt warum von Fallerslebens "Lied der Deutschen“ die falsche Hymne ist, http://www.welt.de/print-welt/article213538/Wolf-Biermannerklaert-warum-von-Fallerslebens-Lied-der-Deutschen-die-falsche-Hymne-ist. html (dostęp: 30.06.2016).

18 B. Brecht, Kinderhymne. Tekst wraz z komentarzem: I. Fetscher, Leidenschaftlich, aber kontrolliert, https://www.bpb.de/system/.../M\%2002.24\%20Kinderhymne.pdf (dostęp: 30.06.2016). 
Protesty jednak na nic się nie zdały. W 1991 roku w ramach korespondencji Helmuta Kohla i Richarda von Weizsäckera za hymn ostatecznie obrano trzecią zwrotkę Pieśni Niemców. Korespondencja między kanclerzem i prezydentem nawiązywała do korespondencji Adenauera z Heussem z 1952 roku w celu legitymizacji i podniesienia rangi wydarzenia. „Dążenie Niemców do jedności na drodze wolnego samostanowienia stanowi centralne przesłanie 3. zwrotki Pieśni Niemców. Dlatego podzielam w imieniu niemieckiego rządu Pana zdanie, że jest ona hymnem narodowym Republiki Federalnej Niemiec"19.

Szansa na „nowy początek” została w ten sposób po raz drugi po 1952 roku zaprzepaszczona, natomiast brak oficjalnego zapisu w ustawie zasadniczej był dla niektórych błędem Adenauera powtórzonym przez Kohla ${ }^{20}$. Według Jürgena Zeichnera pytania o alternatywny hymn dla zjednoczonych Niemiec na poziomie politycznych elit wlaściwie nie zadawano sobie na poważnie. „Wygrana” trzeciej zwrotki Pieśni Niemców była symboliczna również w kontekście walk alternatywnych koncepcji niemiecko-niemieckiej egzystencji ${ }^{21}$.

Na polu symboli narodowych zaznaczyła się przewaga koncepcji Niemiec Zachodnich nad byłą NRD. W 9 lat po zjednoczeniu Heinz Ludwig Arnold połączył hymny byłych Niemiec Wschodnich i Zachodnich, dokumentując w ten sposób trudności niemiecko-niemieckiej egzystencji:

Knirschende Hymne

Einigkeit und aus Ruinen

Recht der Zukunft zugewandt,

Freiheit laß zum Guten dienen

Deutschland einig Vaterland.

Alte Not gilt es zu zwingen

Brüderlich mit Herz und Hand,

Danach laßt uns alle streben,

Und wir zwingen sie vereint.

Einigkeit und Recht und Freiheit,

Daß die Sonne, schön wie nie,

Schein im Glanze unsers Glückes,

Über deutschem Vaterland ${ }^{22}$.

19 Bulletin der Bundesregierung, 27.08.1991, s. 713.

20 J. Zeichner, Einigkeit..., s. 192.

21 Tamże, s. 161.

22 Tamże, s. 191. 
Ustanowienie trzeciej zwrotki hymnem w 1991 roku było zasługą i domeną CDU, która wybrała punkt proklamacji nowego hymnu bardzo starannie - zbiegł się on ze 150. rocznicą powstania Pieśni Niemców. Rozpoczął się boom na hymn, zawrzało w przemyśle płytowym, Deutsche Post wydało z tej okazji znaczki, kartki i pocztówki. Tekst trzeciej zwrotki ze względu na swoją nowo nabytą aktualność nabierał popularności ${ }^{23}$.

Mimo wszelkich kontrowersji wokół hymnu nieznajomość jego tekstu niejednokrotnie bywała publicznie piętnowana. Niemcy doczekali się nawet afery na miarę wykonania polskiego Mazurka Dąbrowskiego przez Edytę Górniak na Mistrzostwach Świata w piłce nożnej w Japonii i Korei w 2002 roku. Trzy lata później niemiecka reprezentacja narodowa grała mecz towarzyski z piłkarzami Bayernu Monachium na otwarcie nowego stadionu klubu, Allianz Arena. Przed spotkaniem hymn zaśpiewała niemiecka piosenkarka Sarah Connor, w obecności 66 tysięcy ludzi zdarzyła jej się pomyłka - zamiast „Blüh im Glanze dieses Glückes” zabrzmiało „Brüh im Lichte dieses Glückes”. Brukowiec Bild podchwycił sprawę, potknięcie nazwał "zawstydzającym”, a następnie zdecydował się przeprowadzić test znajomości tekstu wśród mniej lub bardziej znanych opinii publicznej aktorów, muzyków oraz sportowców. Uschi Glas, Heino czy Ottfried Fischer wykazali się jego perfekcyjną znajomością. Pocieszeniem dla Sary Connor miał być fakt, że wyniki okazały się "zawstydzające” dla innych badanych, gazeta podała liczne przykłady nieprawidłowych interpretacji. Urywek filmu ze śpiewem Connor był wyświetlany we wszystkich programach komediowo-satyrycznych w Niemczech ${ }^{24}$.

Przełomowym wydarzeniem w historii recepcji hymnu stały się Mistrzostwa Świata w piłce nożnej w Niemczech w 2006 roku, niezwykła historia potocznie nazwana, w odniesieniu do Heinricha Heine, das Sommermärchen. Sport odgrywa w niemieckim społeczeństwie istotną rolę. Obrazuje to poniekąd dowcip, iż najważniejszym człowiekiem w Niemczech po Angeli Merkel jest trener niemieckiej reprezentacji w piłce nożnej, Joachim Löw.

Język futbolu jest uniwersalny, każdy go opanował. Piłka nożna łączy intelektualistę z robotnikiem, na krótkie momenty jedna bogatych oraz biednych, w czasach bazującego coraz bardziej na indywidualności świata oferuje jedno z ostatnich wspólnych przeżyć25.

23 Tamże, s. 163, 169.

24 P. Dreyer, A. Hesse, C. Hoffmann, Falsche Hymne im Bayern-Stadion. Sarah Connor: Darum habe ich mich versungen, http://www.bild.de/leute/2005/connor-sarah-sing-unfall-27028.bild.html (dostęp: 30.06. 2016).

25 D. Schulze-Marmeling, Editorial, „Fußball - mehr als ein Spiel. Informationen zur politischen Bildung" 2006, nr 290, s. 3. 
Impreza sportowa to silna koncentracja symboli narodowych - koszulki drużyny, hymn, flaga, ubiór kibiców. Dla wielu niemiecka reprezentacja pozostaje wręcz najważniejszym symbolem narodowym. Nawet osoby nie zainteresowane sportem na co dzień oglądają tzw. „duże imprezy” jak Mistrzostwa Świata i Igrzyska Olimpijskie. Obecność w mediach w Niemczech czyni z piłki nożnej więcej niż sport.

Według powszechnie panującej opinii rok 2006 przyniósł przełom w stosunku Niemców do własnych symboli narodowych, do których młode pokolenie zaczęło podchodzić bez uprzedzeń. Niemcy znów mieli powody do dumy - zaprezentowali się jako dobry gospodarz, a hasło mistrzostw brzmiało „Świat w gościach u przyjaciół”. Symbolem nowych czasów i zmian paradygmatu stał się sposób gry samej reprezentacji. Do tej pory niemieckich piłkarzy na całym świecie łączono z typowymi niemieckimi cnotami - siłą, dokładnością, wręcz topornością. Nowa, młoda reprezentacja pod kierownictwem Jürgena Klinsmanna doczekała się rewolucji - prezentowała szybki, atrakcyjny futbol, który z triumfującą 16 lat wcześniej we Włoszech drużyną Franza Beckenbauera miał niewiele wspólnego. Dla przedstawicieli młodego pokolenia mistrzostwa i reprezentacja były dokładnie takie, jak chcieli widzieć się sami i jak widzieli swój kraj - otwarty, nowoczesny, wielokulturowy. Spiegel pisał o Deutschland-Party, morze czarno-czerwono-złotych flag zalało niemieckie ulice, a w prasie krążyły pojęcia jak „Partyiotyzm” oraz w nawiązaniu do „Das Wunder von Bern” z 1954 roku (zdobyciu pierwszego w historii niemieckiej piłki tytułu mistrzowskiego $\mathrm{z}$ wysoce faworyzowanymi Węgrami) „cud z Berlina”26.

Po mistrzostwach w Niemczech ukazała się nawet osobna publikacja, naświetlająca wszelkie aspekty tej ważnej dla Niemiec imprezy ${ }^{27}$. Według niemieckiego politologa Volkera Kronenberga o cudzie nie mogło być jednak mowy.

W przypadku tego fenomenu, o którym mówimy w kontekście mistrzostw, nie rozchodzi się o niewytłumaczalne, nagłe zdarzenie. Wręcz przeciwnie! Owa symbolicznie wyrażona za pomocą czarno-czerwono-złotych chorągiewek, czapeczek, akcesoriów i tatuaży nieuprzedzona identyfikacja z własną reprezentacją narodową - ale także ponadto to - ze wspólnotą, przykładowo poprzez zupełnie

26 D. Kurbjuweit, K. Allgöwer, K. Brinkbaümer, U. Buse, M. Feldenkirchen, J.-M. Gutsch, B. Hardinghaus, R. Hoppe, M. Kaiser, A. Kneip, J. Kramer, M. Matussek, Deutschland, ein Sommermärchen, „Der Spiegel”, 19.06.2006.

27 E. Hebeker, P. W. Hildmann, Fröhlicher Patriotismus? Eine WM-Nachlese. Argumente und Materialien zum Zeitgeschehen Nr. 57, München 2007. 
oczywiste, wręcz pełne pewności siebie odśpiewanie hymnu - ów jak go szybko określono „radosny patriotyzm” większości Niemców, ma proste do zaobserwowania podstawy w politycznej, społecznej i kulturowej przestrzeni:

1. Czerwono-zielona koalicja: a dokładniej nowe polityczne oraz historyczne pozycjonowanie/justowanie RFN w okresie rządów kanclerza Gerharda Schrödera,

2. Społeczna zmiana pokoloniowa w RFN, związana z demograficznymi wyzwaniami wręcz niewyobrażalnych romiarów oraz połączony z tym

3. Kulturowy proces samoświadomości Niemców w odniesieniu do własnego kraju, między innymi poprzez socjo-moralne warunki bytowe niemieckiej demokracji XXI wieku - proces, w kórego kontekście zadomowiona jest tzw. Leitkulturdebatte (debata nt. kultury wiodącej) ${ }^{28}$.

Jedynie nieliczni krytykowali wszędobylskie chorągiewki na samochodach i zbyt duże nasilenie symboli narodowych. Sama Pieśń Niemców osiągnęła niesamowitą popularność, a wspomniany „Spiegel” nazwał ją w odniesieniu do utworu Schillera Odą do jedności ${ }^{29}$. Pieśń straciła status symbolu narodowego, osiągając poziom piosenki pop. Ukazywało się mnóstwo parodii, nawiązań, wersji alternatywnych. „Niezwykłe w kontekście obejścia z hymnem jest to, że parodie Pieśni Niemców wydają się publicznie akceptowane, w celu politycznej artykulacji”30. Jürgen Zeichner podaje wiele przykładów owych parodii, nawiązań i nowych interpretacji. Jedną z najpopularniejszych było Jedność i prawo do czasu wolnego (Einigkeit und Recht auf Freizeit) zespołu Die-Gerd-Show:

Einigkeit und Recht auf Freizeit

Für das deutsche Vaterland.

Arbeit ist nur was Streber.

Bloß kein Stress und ruhige Hand.

Einigkeit und Recht auf Freizeit,

Eierschaukeln, das entspannt.

Nur nicht schwitzen, bloß nicht bücken,

Für das deutsche Vaterland.

28 V. Kronenberg, Ein Wunder, das keines war. Deutscher Patriotismus im Zeichen der WM 2006, [w:] tamże, s. 98.

29 M. Theile, Ode an die Einheit, „Spiegel Spezial Geschichte” 2007, nr 1, s. 108-109.

30 J. Zeichner, Einigkeit..., s. 200. 
Urlaub, Urlaub über alles

Über alles in der Welt.

Geil sind auch die Kaffeepausen,

Da vergeht ein Tag ganz schnell.

Nase bohren, Zeitung lesen,

Mal ein Spielchen am PC.

Und schon wieder Feierabend,

tierisch, wie die Zeit vergeht ${ }^{31}$.

W związku z nasilającą się imigracją ludności do Niemiec pojawił się postulat przetłumaczenia słów hymnu na język turecki. Ostrą krytyką zareagował związek okręgowy Junge Union Esslingen na żądanie polityka partii zielonych Hansa-Christiana Ströbele o oficjalną turecką wersję hymnu narodowego. W opinii przewodniczącego Philipa Königa żądanie zaprzecza wszelkim staraniom w celu lepszej integracji migrantów w Niemczech. „To właśnie język niemiecki jest jednym z najważniejszych składowych udanej integracji, a od każdego migranta wymagana jest jego nauka. Nie-niemieckojęzyczny hymn narodowy mógłby stać się niejako »hymnem niechętnych «. Istniejące społeczeństwa równoległe zostałyby przez państwo dodatkowo wzmocnione" 32 .

Kontynuację zmieniającego się paradygmatu w podejściu do Pieśni Niemców oraz kolejny etap w wydawałoby się niekończącej się debacie na jej temat można było zaobserwować w ramach innej dużej imprezy sportowej, Mistrzostw Europy w piłce nożnej w 2012 roku w Polsce i na Ukrainie. Boateng, Khedira, Özil - młodzi piłkarze z tzw. tłem migracyjnym (Migrationshintegrund) stanowili silny trzon reprezentacji Niemiec. Każdy z wymienionych piłkarzy urodził się, wychował i chodził do szkoły w Niemczech, każdy z nich posługuje się językiem niemieckim - jednak przed meczami milczeli, kiedy brzmiał niemiecki hymn, według wypowiedzi z szacunku dla ojczyzn własnych rodziców.

Niemcy w półfinale w Warszawie doznali porażki z reprezentacją Włoch, której piłkarze przed meczem bark w bark pełnym gardłem intonowali własny hymn narodowy, Fratteli d’Italia, „Bracia Włosi, Italia się budzi. Zewrzyjmy szeregi, gotowi na śmierć, gotowi na śmierć, Italia wezwała!”. Z podobną namiętnością i wolą walki prezentowali się później na boisku, podczas gdy połowa Niemców potulnie milczała i tak też później grała. Wnioski nasunęły

31 Tamże, s. 193.

32 Junge Union gegen Nationalhymne auf Türkisch, http://www.ju-es.de/archives/11Junge-Union-gegen-Nationalhymne-auf-tuerkisch.html (dostęp: 30.06. 2016). 
się same, a po kolejnej nieudanej próbie wygrania dużej imprezy w Niemczech zaczęto szukać winnych.

Wybuchła afera o wymiarze politycznym. Politycy, w tym Prezes Rady Ministrów Hesji i Prezydent Bundesratu Volker Bouffier (CDU), Minister Spraw Wewnętrznych Hesji Boris Rhein (CDU), ekspert od spraw wewnętrznych Hans-Peter Uhl (CSU), Minister Spraw Wewnętrznych Bawarii Joachim Hermann (CSU) w wypowiedziach dla niemieckiego Bilda zaczęli domagać się wprowadzenia tzw. „Singpflicht”, czyli obowiązku śpiewania hymnu przed meczem. „Śpiewanie hymnu powinno należeć do dobrego tonu. Grają przecież dla niemieckiej reprezentacji narodowej, a nie dla siebie! Wstyd, że w ogóle musimy o tym dyskutować, w zasadzie gracze sami powinni na to wpaść!" (Bouffier), „kto nie ma ochoty śpiewać, powinien zostać w swoim klubie” (Herrmann), "gra dla Niemiec to zaszczyt, piłkarze są ambasadorami Niemiec, dla każdego śpiewanie powinno być więc sprawą oczywistą” (Schünemann), „nie mogę wybiec na boisko w barwach reprezentacji i zgarniać idące $\mathrm{z}$ tego tytułu korzyści, a następnie udawać, jakbym był tylko na wpół Niemcem" (Mayer -Vorfelder) ${ }^{33}$. Pikanterii sprawie dodawał fakt, iż nierzadko ci sami politycy i działacze po Mistrzostwach Świata w 2010 roku w RPA określili niemiecką reprezentację idealnym przykładem udanej integracji migrantów. Atmosferę podgrzał sam „cesarz” Franz Beckenbauer, który przed Mistrzostwami 1990 roku we Włoszech nakazał swoim piłkarzom śpiewanie hymnu stwierdzając, że reprezentacja RFN dzięki temu została mistrzem świata.

Wprowadzenie „obowiązku śpiewania” spotkało się z dużą falą krytyki w niemieckiej prasie, która węszyła powrót do „przeddemokratycznych czasów” oraz „brak szacunku wobec skomplikowanej biografii młodych ludzi” ${ }^{34}$. W imieniu piłkarzy bronił się Sami Khedira:

Dla mnie dobrym Niemcem jest ktoś, kto posługuje się językiem, akceptuje zwyczaje oraz wartości państwa. A to robi każdy z nas. Redukowanie nas do nieśpiewania hymnu i mówienie, że nie jesteśmy prawdziwymi Niemcami, jest po prostu nie fair ${ }^{35}$.

33 A. Baldauf, M. Kluckert, R. Schuler, W. Straten, F. Solms-Laubach, BILD.de-User fordern. Singpflicht für Fußball-Stars, http://www.bild.de/politik/inland/nationalmannschaft/ riesen-wirbel-um-unsere-nationalhymne-24948084.bild.html (dostęp: 30.06.2016).

34 K. Hoeltzenbein, Bloß keine Sangespflicht!, http://www.sueddeutsche.de/sport/hymnendebatte-um-die-dfb-elf-bloss-keine-sangespflicht-1.1442001 (dostęp: 30.06.2016).

35 T. Hummel, Sami Khedira wehrt sich im Hymnen-Streit, http://www.sueddeutsche.de /sport/deutsche-nationalmannschaft-sami-khedira-wehrt-sich-im-hymnen-streit1.1441380 (dostęp: 30.06. 2016). 
Jak się okazało duża część opinii publicznej od sportowców niemieckich reprezentacji narodowych oczekiwała śpiewania hymnu przed zawodami, a odmowa potraktowana została na równi z brakiem identyfikacji z narodowymi wartościami. Obrazowały to liczne listy czytelników do redakcji, głosy w debatach telewizyjnych oraz niezliczone komentarze $w$ internecie ${ }^{36}$. W jednym $\mathrm{z}$ nich komentujący w celu podparcia swej tezy posłużył się wypowiedzią kanclerza Helmuta Schmidta: „Integracja to iluzja intelektualistów”37. Absurdalność całej dyskusji została udowodniona parę dni później - w finale śpiewający z całego serca Włosi zostali boleśnie pokonani przez reprezentację Hiszpanii, której piłkarze nie śpiewają przed meczem - ich hymn po prostu nie posiada tekstu.

Łatwo przeoczyć wynikający z afery wniosek. Nastąpiła swoista zmiana paradygmatu - dyskusja obracała się wokół „śpiewać czy nie śpiewać”, nikt nie dyskutował natomiast „co śpiewać”, tudzież „który hymn”. Odpowiedź była oczywista - trzecia zwrotka Pieśni Niemców wydawała się umacniać na pozycji powszechnie akceptowanego hymnu narodowego.

Sytuacja prawna dotycząca hymnu była wielokrotnie przedmiotem sporów prawników - na ten moment nie ma bowiem oficjalnego zapisu, który czyniłby z Pieśni Niemców hymn narodowy. Korespondencja Kohla z von Weizsäckerem z 1991 roku musiała wystarczyć, a po zjednoczeniu w ustawie zasadniczej zmieniono jedynie zapis dotyczący stolicy. Ciekawym w tym kontekście jest porównanie zapisów w polskiej i niemieckiej konstytucji.

\section{Niemiecka ustawa zasadnicza}

II. Der Bund und die Länder (Art. 20-37)

Artikel 22

[Hauptstadt Berlin; Bundesflagge]

(1) Die Hauptstadt der Bundesrepublik Deutschland ist Berlin. Die Repräsentation des Gesamtstaates in der Hauptstadt ist Aufgabe des Bundes. Das Nähere wird durch Bundesgesetz geregelt.

(2) Die Bundesflagge ist schwarz-rot-gold ${ }^{38}$.

36 Pod jednym z filmów na Youtube, na którym niemieccy piłkarze nie intonują hymnu narodowego, wylała się fala krytyki: „To wstyd, że Özil i spółka nie śpiewają hymnu, najważniejsze to brać kasę z DFB/Śpiewanie hymnu powinno być dowodem dobrej integracji. Nie wystawiałbym piłkarzy którzy wzbraniają się przed jego śpiewaniem/ Śpiewanie powinno być okazaniem szacunku/Nie podoba mi się, że wystarczająco identyfikują się z Niemcami, aby nosić koszulkę reprezentacji, ale już nie na tyle, aby nie śpiewać hymnu narodowego, do tego w kontekście historycznym tak udanego", https://www.youtube.com/watch?v=YppKq73XN48 (dostęp: 30.06.2016). Tamże.

38 Grundgesetz für die Bundesrepublik Deutschland, https://www.bundestag.de/bundestag/aufgaben/rechtsgrundlagen/grundgesetz/gg_02/245124, (dostęp: 30.06.2016). 


\section{Konstytucja Rzeczypospolitej Polskiej}

Art. 28.

(1) Godłem Rzeczypospolitej Polskiej jest wizerunek orła białego w koronie w czerwonym polu.

(2) Barwami Rzeczypospolitej Polskiej są kolory biały i czerwony.

(3) Hymnem Rzeczypospolitej Polskiej jest Mazurek Dąbrowskiego.

(4) Godło, barwy i hymn Rzeczypospolitej Polskiej podlegają ochronie prawnej.

(5) Szczegóły dotyczące godła, barw i hymnu określa ustawa.

Art. 29.

Stolicą Rzeczypospolitej Polskiej jest Warszawa ${ }^{39}$.

$\mathrm{Z}$ brakiem regulacji prawnej związany jest ostatni jak dotąd etap w odysei związanej z hymnem, który miał miejsce w grudniu 2015 roku w ramach kryzysu uchodźczego w Europie. CDU na swoim zjeździe partyjnym w Karlsruhe poparła wniosek Junge Union, wnoszącej o przyjęcie zapisu o hymnie narodowym do ustawy zasadniczej. „To bez wątpienie jest symbol” powiedział przewodniczący JU Paul Ziemiak. „Właśnie teraz, kiedy przyjeżdża do nas tak wielu ludzi, powinniśmy wysłać sygnał, że nasz hymn narodowy wyraża to, co czujemy"40. Według uchwały artykuł 22. ustawy zasadniczej ma być uzupełniony o passus „Hymnem narodowym Republiki Federalnej Niemiec jest trzecia zwrotka Pieśni Niemców z tekstem Augusta Heinricha Hoffmanna von Fallerslebena i melodią Josepha Haydna”. CDU nawołuje rząd, aby wstawił się za uzupełnieniem dotychczasowego zapisu: „flaga jest czarno-czerwono-złota”.

Zmiana w konstytucji wymaga 2/3 głosów, politycy SPD sygnalizują jednak odmowę, co obrazuje m.in. komentarz zastępcy przewodniczącego SPD, Ralfa Stegnera:

Mamy ładny hymn narodowy, którego chętnie słucham przy okazji uroczystości oraz imprez sportowych. Kto w tych trudnych czasach stawia jedynie na politykę symboliczną oraz urabianie opinii publicznej, jak czyni to wielu konserwatystów i prawicowych populistów, nie zrozumiał, co naprawdę oznacza polityczna odpowiedzialność. Powinniśmy zatem rozwiązywać realne codzienne problemy ludzi, a nie problemy pozorne" 41

39 Konstytucja Rzeczypospolitej Polskiej, http://www.sejm.gov.pl/prawo/konst/polski/ kon1.htm (dostęp: 30.06.2016).

40 CDU will Nationalhymne im Grundgesetz verankern, http://www.zeit.de/politik/deutschland/2015-12/cdu-parteitag-angela-merkel-grundgesetz-nationalhymne (dostęp: 30.06.2016).

$41 \quad$ R. Miller, SPD wittert Scheindebatte. Junge Union (JU) will Deutschlandlied im Grundgesetz verankern, https://www.hessen-depesche.de/politik/junge-union-ju-will-deutschlandliedim-grundgesetz-verankern.html (dostęp: 30.06.2016). 
Socjaldemokraci na zakończenie swoich zjazdów partyjnych nadal śpiewają własny hymn: „Wann wir schreiten Seit an Seit...”.

Warto również zwrócić uwagę na katalog 300 pytań wprowadzonego w 2012 roku niemieckiego testu na obywatelstwo. Znalazły się w nim jedynie dwa pytania odnośnie niemieckiego hymnu: „Jakimi słowami zaczyna się niemiecki hymn narodowy?" (Mit welchen Worten beginnt die deutsche $\mathrm{Na}$ tionalhymne?) oraz „Kto napisał słowa niemieckiego hymnu narodowego?“ (Wer schrieb den Text zur deutschen Nationalhymne?) ${ }^{42}$. Znajomość całego tekstu hymnu nie jest od kandydatów na obywateli niemieckich wymagana.

Podsumowując - po 1990 roku trzecia zwrotka Pieśni Niemców stała się odbiciem nowej politycznej rzeczywistości, a zjednoczenie przyniosło spełnienie stawianych przez Hoffmanna postulatów. Na przestrzeni lat stosunek do niemieckiego hymnu był wielokrotnie elementem gry politycznej. Z biegiem czasu trzecia zwrotka stała się symbolem demokratycznego państwa parlamentarnego i w tym leży jej niewątpliwy sukces. Stosunek społeczeństwa niemieckiego do symboli narodowych wciąż naładowany jest emocjami, u większości cieszą się one jednak akceptacją.

Ważną rolę w procesie popularyzacji osoby Hoffmanna von Fallerslebena oraz trzeciej zwrotki hymnu odegrała również działalność Towarzystwa Naukowego im. Hoffmanna von Fallerslebena (Hoffmann-von-Fallersleben-Gesellschaft) i jego prezydenta Kurta Schustera. Popularyzacja osoby i twórczości autora tekstu, Hoffmanna von Fallerslebena, trzy międzynarodowe sympozja naukowe z czwartym zaplanowanym na 2017 rok, monografie naukowe, edycje korespondencji, zbiory wierszy, biografie i nowo otwarta wystawa oddemonizowały autora i pozbawiły go ciążącej nad nim „szowinistycznej reputacji”"43.

42 Einbürgerungstest. Fragenkatalog zur Testvorbereitung, Bundesamt für Migration und Flüchtlinge (test na obywatelstwo na stronie Urzędu Federalnego ds. Migracji i Integracji), http://oet.bamf.de/pls/oetut/f?p=514:1:6960474062631 (dostęp: 30.06.2016).

43 Na temat recepcji hymnu niemieckiego por. K. Schellenberg, Die Nationalhymne - eine deutsche Geschichte, [w:] Hoffmann von Fallersleben. Dichter, Germanist und singender Freiheitskämpfer. Begleitbuch zur Dauerausstellung des Hoffmann-von-Fallersleben-Museums, B. Greffrath, G. Henkel, C. Langermann (red.), Hildesheim, Zürich, New York 2015, s. 213-233; E. Rohse, „Das Lied der Deutschen” in seiner politischen, literarischen und literaturwissenschaftlichen Rezeption, [w:] August Heinrich Hoffmann von Fallersleben 1798-1998. Festschrift zum 200. Geburtstag, H.-J. Behr, H. Blume, E. Rohse (red.), Bielefeld 1999, s. 51-100; H. Blume, Maas, Memel, Etsch und Belt. Die Gewässer in Hoffmanns Lied der Deutschen und die Grenzen des 
Jeśli dziś śpiewana jest jedynie ta trzecia zwrotka hymnu, to ze względu na doświadczenia nacjonalistycznych złych dróg w naszej historii. Niemcy pokazują w ten sposób również, jakim podstawowym wartościom i demokratycznym tradycją są dziś zobowiązane. „Jedność, prawo i wolność” - to nierozłączne warunki dla powstania pokojowej, socjalnej i humanitarnej wspólnoty w sercu Europy ${ }^{44}$.

W obliczu braku ostatecznych uregulowań prawnych historia recepcji Pieśni Niemców czeka natomiast wciąż na swoje pozytywne zakończenie.

\section{Zusammenfassung}

Nur wenige Texte können auf eine so lange, und gleichzeitig so facettenreiche Tradition zurückblicken, wie das 1841 von August Heinrich Hoffmann von Fallersleben (1798-1874) verfasste Lied der Deutschen. Dabei spielt die Nationalhymne in der Rezeptionsgeschichte der deutschen Nationalsymbole eine besondere Rolle und bedarf einer ständigen Aktualisierung. Im Aufsatz wird das Bild des schwierigen Verhältnisses der Deutschen zu ihren Nationalsymbolen gezeichnet und die reiche Rezeptionsgeschichte des Liedes der Deutschen vor und nach der Wiedervereinigung 1990 zusammengefasst - zu Lebzeiten des Verfassers, während des ersten Weltkriegs und der Weimarer Republik. Thematisiert werden sowohl der Missbrauch durch die Nationalsozialisten und die Doppelhymne mit dem Horst Wessel Lied, als auch die Hymnendebatte in der Bundesrepublik nach dem Zweiten Weltkrieg. Der Vorschlag der Jungen Union, das Lied der Deutschen im Grundgesetz zu verankern, die Fragen zum Text und Autor im aktuellen Einbürgerungstest, die Hymnendebatte rund um die Fußball Nationalmannschaft nach der WM 2010 und der EM 2012, nicht zuletzt die Bedeutung und Aktualität des Textes im Zeichen der Massenmigration und der Flüchtlingskrise - im Artikel werden die neuesten Entwicklungen der Rezeptionsgeschichte aus einer kulturwissenschaftlichen Perspektive nachgezeichnet.

\section{Bibliografia}

BEHR H.-J., BLUME H., ROHSE E. (red.), August Heinrich Hoffmann von Fallersleben 1798-1998. Festschrift zum 200. Geburtstag, Bielefeld 1999.

DEDE K., Die missbrauchte Hymne. Ein Plädoyer von Klaus Dede, Osnabrück 1989.

„Vaterlandes”, [w:] Hoffmann von Fallersleben. Internationales Symposion Wrocław/ Breslau 2003, M. Hałub, K.G.P. Schuster (red.), Bielefeld 2005, s. 247-266.

${ }^{44}$ K. Schellenberg, Die Nationalhymne, s. 213. 
EINBÜRGERUNGSTEST. Fragenkatalog zur Testvorbereitung, Bundesamt für Migration und Flüchtlinge, http://oet.bamf.de/pls/oetut/f?p=514:1:69604 74062631 (dostęp: 30.06.2016).

GÖSSMANN W., ROTH K.-H., Poetisierung - Politisierung. Deutschlandbilder in der Literatur bis 1848, Paderborn-München-Wien-Zürich 1994.

GREFFRATH B., HENKEL G., LANGERMANN CH. (red.), Hoffmann von Fallersleben. Dichter, Germanist und singender Freiheitskämpfer. Begleitbuch zur Dauerausstellung des Hoffmann-von-Fallersleben-Museums, Hildesheim-Zürich-New York 2015.

GRUNDGESETZ für die Bundesrepublik Deutschland, www.bundestag.de/ bundestag/aufgaben/rechtsgrundlagen/grundgesetz/gg_02/245124 (dostęp: 30.06.2016).

HAŁUB M., SCHUSTER K.G.P., Hoffmann von Fallersleben. Internationales Symposion Wrocław/Breslau 2003, Bielefeld 2005.

KONSTYTUCJA Rzeczypospolitej Polskiej, www.sejm.gov.pl/prawo/konst/ polski/kon1.htm (dostęp: 30.06.2016).

KURZKE H., Hymnen und Lieder der Deutschen, Mainz 1990.

ORTMEYER B., Argumente gegen das Deutschlandlied. Geschichte und Gegenwart eines furchtbaren Lobliedes auf die deutsche Nation, Frankfurt am Main 2006.

REICHEL P., Schwarz-Rot-Gold. Kleine Geschichte deutscher Nationalsymbole nach 1945, München 2005.

SCHULZ K.P., „Deutschland, Deutschland über alles”. Persönliche Bemerkung zur Nationalhymne, „Gewerkschaftliche Monatshefte”, 1952, nr 6.

ZEICHNER J., Einigkeit und Recht und Freiheit. Zur Rezeptionsgeschichte von Text und Melodie des Deutschlandliedes seit 1933, Köln 2008.

www.bild.de

www.bundesregierung.de www.hessen-depesche.de www.ju-es.de www.welt.de 